\title{
ECONOMIC SANCTIONS AND GLOBALIZATION: ASSESSING THE IMPACT OF THE GLOBALIZATION LEVEL OF TARGET STATE ON SANCTIONS EFFICACY ${ }^{1}$
}

\author{
DOI: 10.17261/Pressacademia.2019.1027
}

JEFA- V.6-ISS.1-2019(4)-p.41-54

\section{Murad Duzcu}

Hatay Mustafa Kemal University, Department of International Relations, Tayfur Sökmen Kampüsü, 31060, Antakya, Hatay, Turkey. muradduzcu@mku.edu.tr, ORCID: 0000-0001-5587-4774

To cite this document

Duzcu, M. (2019). Economic sanctions and globalization: Assessing the impact of the globalization level of target state on sanctions efficacy. Journal of Economics, Finance and Accounting (JEFA), V.6(1), p.41-54.

Permemant link to this document: http://doi.org/10.17261/Pressacademia.2019.1027

Copyright: Published by PressAcademia and limited licenced re-use rights only.

\begin{abstract}
Purpose - When do states resist the threat of sanctions or comply with the demands of the political unit imposing sanctions? This article argues that if the target has a high globalization index, it conforms to the demands of the sender. Therefore, the article examines the impact of target's globalization level on the initiation and success of economic sanctions as a frequently used foreign policy tool.

Methodology - In combination of two datasets, (for sanctions cases, Hufbauer et al, 2007; and for globalization index Raab et al, 2007), this article, uses 72 sanctions cases from Hufbauer et al. (2007) dataset to examine some indicators of sanctions efficacy. A probit model is used to analyze the hypotheses.

Findings - The findings of the empirical models presented in the article, reveal a positive relationship between the efficacy of economic sanctions and the high level of globalization in target state. Thus, as targets become globalized, the efficacy of sanctions increases. Empirical evidence has been found in the models as the relationship between sanctions success and globalization has been indicated, since cultural globalization index is used as an indicator of regime type and, most importantly, due to the presumed relationship between winning coalitions and cultural globalization.

Conclusion - It has been found that cultural globalization leads to political change that causes transitional political systems to emerge for such states. Referring to the selectorate theory, it is claimed that the winning coalition is possibly wider and the scope of this coalition can be determined without identifying a regime type for the target. In addition, cultural globalization leads to social change that may affect public opinion. As such the audience costs are higher in culturally globalized targets because it requires a publicly accepted foreign policy behavior.
\end{abstract}

Keywords: Economic sanctions, globalization, sanctions efficacy, compliance, human rights, financial sanctions.

JEL Codes: D80, F10, F51, F60, N40

\section{INTRODUCTION}

One of the main challenges for a sanctioning state is to effectively influence the sanctions behavior of the target state. In general, sanctions have long been used by state and non-state actors as an important foreign policy tool for this purpose (Eland, 1995). Imposing economic sanctions became widespread in the 1990s (see Cortright and Lopez, 2000), and the international community has started to pay more attention to the effectiveness of sanctions since then as sanctions often failed to achieve the policy goals. Also, in the past decades, social scientists have been trying to explain why states resist or fail to comply with sanction demands. As a result of this dilemma, sanctions have been highly criticized for failing to change the behavior of the target state (see Knorr, 1975; Pape, 1997). On the contrary, the claims of the advocates that sanction is an effective means are that sanctions can, in some cases, reach certain policy goals (see Hufbauer et al., 1990). These different points of view arise from a fundamental problem: Why do some target states respond to the demands of the sanctioning state, while some other states resist the consequences of economic sanctions?

${ }^{1}$ This manuscript is part of author's master's thesis of Florida State University. 
Historically, sanctions are similar to a medieval siege (Simons, 1999). As any siege may indicate, the result of such a strategy is determined by the isolation and the costs incurred on the encircled political entity. The empirical relationship between the target costs and sanctions success is confirmed in line with negative reflections of siege (see Hufbauer et al., 1990; Lam, 1990; Dashti-Gibson et al., 1997; Drury, 1998). However, the only factor for sanctions success is not to increase the target costs as much as possible. Among other determinants, it was argued that the outcome of a sanctions episode is highly dependent on the internal political characteristics of the target state (Morgan and Schwebach, 1996; Allen, 2005; Lektzian and Souva, 2007; Cox and Drury, 2006; Bolks and Al-Sowayel, 2000; Nooruddin, 2002). Political negotiations within a state, which are limited by the demands of the sanctioning state and the interests of domestic political actors, may affect the outcome of sanctions (Morgan and Schwebach, 1996: 250). In particular, the differences between the interests of political actors refer to the regime type of the sender and target states. In other words, the impact of the regime type on sanctions, is partly due to the relationship between leadership and constituencies. In democracies, the size of individual actors (selectorate) and constituencies who choose political leaders (winning coalition) are higher than in autocratic states (Bueno de Mesquita et al., 1999).

Democratic states try to maintain a broad winning coalition. As such, democratic leaders often tend to pursue "friendly" foreign policy strategies to stay in the political office and avoid the impact of armed conflict on the general public (see McGillivray and Smith, 2000). Such an assumption leads to democratic accountability of the leaders. In this context, Nossal (1999), for example, argues that democratic leaders concede to sanctions in order to reduce the costs of sanctions imposed on the target population (p.130). Similarly, because sanctions inflict various and often increasing costs for the population of the target state; as Nooruddin (2002) argued, democratic leaders are responsible to the public for the cost of sanctions; therefore, when sanctions are imposed on a democratic target, the political behavior of the democratic leader changes (p.69-70). In case the sanctions are imposed on autocratic targets, as the autocratic leader is assumed to meet the needs and gain the support of a small winning coalition, they do not have any concerns or reasons for providing public goods to the target population to preserve their political statuses (Lektzian and Souva 2007, s.852-853). This situation, increases the likelihood of sanctions success when imposed on non-democratic states.

However, sanctions as a means of economic coercion are also similar to bargaining games. To this end, Fearon's (1994) audience costs approach assumes that leaders are limited to domestic public opinion. Audience costs are produced by local leaders who increase the expectations of the public during the crisis period and consequently these expectations limit the leader to follow the declared course of action. Fearon argues that democracies incur more audience costs than in autocratic states. However, due to the presence of wider size of winning coalition in democracies and its aforementioned relevance to sanctions success, autocratic leaders are more likely to change their political behavior when faced with economic sanctions because of relatively small audience costs, as autocrats have more maneuverability than democratic leaders (Kaempfer and Lowenberg 2007). In other words, when democratic leaders resist sanctions to avoid any possibility of a political failure, sanctions against autocratic targets become a more realistic option.

In the light of these claims, sanctions scholars provide controversial views on both the initiation and enforcement of sanctions. For example, as autocratic states are more likely to be targets of sanctions than democratic states (Cox and Drury 2006), and because democratic states impose sanctions more often than others (Lektzian and Souva 2007); the sanctions imposed against autocratic states, as a hypothetical but frequently occurring issue (democratic-autocratic sanctions dyads) must also be successful. The sanctions imposed by democratic political actors will increase the likelihood of success due to high audience costs. However, the correlation between the regime type and sanctions success requires a reassessment of the existing theories for their use in various sanctions cases.

This article develops a different context for understanding the effectiveness of sanctions with a special emphasis on target characteristics. The hypotheses associated with the impact of globalization on the domestic political structures of the target and its compliance with the sanction demands. In this regard, cultural globalization is used as a measure of the domestic political dynamics of the target. Moreover, assuming the structural characteristics of the internal political institutions of the target as an important criterion for sanctions success; the typology of regime type for target is a partly meaningful indicator for the target to comply with the sender's demands. Simply put, the classification of the target's regime type as democratic or autocratic, ignores the interaction between the preferences and expectations of the population and the leadership of the target. In other words, the winning coalition in autocratic regimes are wider than the one we may assume if the autocratic state has a higher globalization level. In the Hufbauer et al. (2007) dataset, some cases of sanctions, including democratic targets with relatively lower cultural globalization levels, were coded as a failure; on the contrary, others with autocratic states with higher cultural globalization levels were coded as successful sanctions cases. To this end, cultural globalization is used as a key measure of the "social and psychological circumstances in the target society" (Galtung 1967, p.28) that is expected to determine the extent of the target's response to sanctions.

Also, interest in public preferences requires an analysis of the perceptions of sanction in the public eye. In this sense, policy goals affect sanctions not only from sender's point of view, but also from the view of target population. For the population 
of the target and domestic political actors, a trade-off exists between the target's policies and the sanctions goals, so they may have to decide which is more important. The changes anticipated by the sender with sanctions (such as human rights or democratization) may be more appealing to the public due to the difficulty of embracing domestic policies of the target state. The second assumption, then, should be that the public perception of sanctions should not be valued independently of the characteristics of the sender state's policy goals. In order to shed light on the differences in the perceptions of public regarding sanctions, the target's public support towards policy goals of the sender, such as the human rights conditions of the target can replace the support of the policies of the target's government. The policy objectives that will not address the interests of the target's population will have a negative impact on sanctions success.

To these ends, the following sections will elaborate on the nexus between sanctions success and globalization, and some correlates of efficacy of sanctions that are frequently discussed in the sanctions research, which are also included in the empirical models of the article.

\section{SANCTIONS SUCCESS AND CULTURAL GLOBALIZATION}

The effectiveness of sanctions is often articulated through the aspects of sanctions policy and bilateral relations between the sender and target. In addition, recent studies draw attention to the characteristics of target in terms of the impact of domestic political institutions of the target. A second stream of research refers to the regime type of both sides of sanctions as one of the main determinants of sanctions success. This section, therefore, presents a framework for the link between cultural globalization and sanctions success by evaluating both the policy features of sanctions and domestic political characteristics of the targets. In this context, this research combines, some of the independent variables presented in sanctions research, such as the economic cost to the target, international cooperation, and the economic and political stability of the target state, with the empirical models presented in this article. Indicators, such as policy goals and regime type, are considered as a part of the arguments that are supposed to be substituted or accompanied by the cultural globalization variable. For this reason, the following section describes the predicted relationship between the sanctions success and cultural globalization, and their relationship to bilateral relations and regime type. Next, the argument on the relationship between policy goals and public perceptions of sanctions will be examined.

\subsection{Sanctions Success and Cultural Globalization}

Globalization refers to the "real changes of fundamental importance" that may influence the political, economic and social structures of a society (Keohane and Nye 2000, p. 4). As such, the idea is about the transformation of domestic institutions, which is also exemplified as the penetration of global economic and financial assets into the local market. Developments in information and communication technology accelerated the spread and speed of globalization. These conditions lead to economic, social and political change in a given society. In contrast, such changes affect the target's political behavior and the perceptions of sanctions by the public in terms of sanctions. In other words, globalization level in a society increases the public consciousness about the sanctions to an extent in the target, that is to say, changes the preferences of the public about it. So, globalization increases both the exposure of target to external influence, and its adaptation to global values and standards. For example, the socio-political change in the ex-Soviet periphery, in the aftermath of the Cold War, through a shift to the market economy, shows how globalization has transformed the socio-political and economic infrastructure of the former Soviet republics.

In this regard, the cultural globalization level in a society becomes a measure of both state behavior and perceptions of the public, regardless of the effects of regime type on both concepts. In other words, cultural globalization refers to an 'invisible hand' that affects the resolve of the target state against sanctions and perceptions of it by the public once the sanctions is imposed. As a concept embedded in the political and social structures of a society, cultural globalization is thus regarded as an indicator that measures the general state of affairs in a society in the course of a transition from one state to another. In this sense, the target may have different levels of resolve, due to aforementioned domestic and external vulnerabilities, when sanctions are imposed over different time periods.

Therefore, it can be argued that there is evidence that globalization has an impact on the effectiveness of sanctions for two reasons. First, as it is more likely to punish an ally with economic measures than an adversary, cultural globalization concept is used to replace the alliance relationship between the target and sender. Because of the likely influence of globalization on state behavior, the globalized target is expected to act in accordance with the will of international community (such as compliance to the UN resolutions). Second, as sanctions success depends in part on the nature and extent of local political constraints, cultural globalization increases the target's audience costs, irrespective of the domestic political systems of the target.

\section{Prior Relationship and Sanctions Success}

In Economic Sanctions Reconsidered, Hufbauer et al. (1985), have proved that sanctions are more successful if the target is "either an ally, or at least neutral and on friendly terms" with the sender. For example, the index of prior relations in a 
successful sanctions case, such as the United States vs. the Netherlands, is 2.3 out of 3. Similarly, Drezner (2001) argues that the sender take into account the opportunity cost and future conflict expectations when they impose economic coercion measures (p.390). As Drezner points out, the sender prefers to impose sanctions on adversaries rather than allies; however, the sender obtain more concessions from an adversary than an ally. Drezner's theory assumes that allies with low levels of conflict expectations prefer to prioritize 'relative gains' and try to maintain cordial relations with the sender. On the other hand, an adversary attach importance to its 'absolute gains' and have a high level of conflict expectations, so they prefer to adopt a more firm policy stance at present, to eliminate future concessions (Drezner 2001, s.390-391). In other words, in anticipation of a future hostile relationship, an adversary is less responsive to the threat of sanctions than an ally that are likely to maintain an alliance relationship in the near future. The US economic coercion against South Korea, for example, which hindered Korea's desire to develop nuclear weapons, can be considered as one of the examples of the theory of conflict expectations (p.251).

In addition to these assumptions, it is argued that as societies are more globalized, the commitment to universal values and standards, which may be considered as a substitute for the alliance relationship, will increase the effectiveness of economic sanctions. In fact, both globalization and some sanctions cases serve to similar purposes. For example, when the objective of sanctions is democratization, the target is often compelled to conform to the policy goal of the sender while accepting democratic norms as a natural process and as part of the social change through globalization. To sum up, measuring the target's compliance with a cultural globalization index variable, may substitute the ally and adversary dichotomy, which means that globalized states are supposed to adhere universal values and standards, and are part of a global informal alliance when it comes to the sender and target relations.

\section{Regime Type and Sanctions Success}

In addition to the central premise of Hufbauer et al. (1985), scholars also pay attention to the domestic political features of the target (Morgan and Schwebach 1996; Allen 2005; Lektzian and Souva 2007; Cox and Drury; Bolks and Al-Sowayel 2000; Nooruddin 2000). The assumption about the regime type and sanctions success is an extension of the democratic peace theory. Likewise, because of the lower likelihood of two democracies fighting each other, sanctions as a policy tool hardly take place between democratic dyads (Lektzian and Souva 2007). Moreover, democratic leaders seek to avoid the cost of sanctions imposed on the local population to preserve their political statuses (Bueno de Mesquita and Siverson 1995). Similarly, in relation to the selectorate theory, democratic leaders must meet the demands of a large winning coalition (key constituencies for re-election) and provide public goods such as national security. On the contrary, autocratic leaders only provide some special goods because the size of their key supporters is relatively small (Lektzian and Souva 2007; Allen 2005). Moreover, in order to eliminate the cost of sanctions to the public, leaders not only pursue peaceful foreign policies but also comply with the sanctions demands (Bolks and Al-Sowayel 2000; Nooruddin 2000).

Similarly, Fearon (1994) argues that democracies have higher audience costs and democratic leaders are more responsible for constituencies than in autocratic regimes. Thus, in the case of a crisis escalation situation that Fearon modeled in his study, following the escalation of crisis, the party whose audience costs are higher is more likely to back down than the one whose costs are lower. Because a leader increases the expectations of the local population for a specific foreign policy goal, leaders often bind themselves to the public to maintain the declared policy stance. Audience costs are then the penalties of the leader in the case of a policy failure. In spite of the presence of wider winning coalitions in democracies, autocratic leaders are more likely to change behavior, as autocrats can change adopted policies since they have lower audience costs (Kaempfer and Lowenberg 2007). Hence, the assumption of audience costs can be extended to cultural globalization, which points to the level of political and social structures of the target. This is a situation that assumes the existence of democratic norms in a society, and also takes into account the preferences of the target's population. In sum, it is expected that high level of cultural globalization increases audience costs, which in turn increases the likelihood of sanctions success.

Tomz (2007) finds empirical evidence to support the existence of audience costs on international political issues, concluding that these costs are "especially evident among politically active citizens" and "international reputation of a country or a leader" are of interest to those citizens. Tomz, using embedded experiments in public surveys, measures the degree of audience costs in crisis times. This article employs cultural globalization to assess the degree of audience costs in cases of sanctions (political crisis), especially in the absence of such data for each sanctions case. As already mentioned earlier, the typology of regime type can be misleading as an indicator of evaluation of target's public attitudes and political system, since the characteristics of such a dichotomous variable provide merely limited and sometimes censored information about the political and social structure of a given society. In other words, as Tomz points out the importance of politically active citizens, the use of cultural globalization as a criterion and indicator implies the existence of such features of a group of citizens within a society. As a sub-variable that measures the extent of political and civil rights of citizens and the impact of globalization on the social cohesion and change, cultural globalization as a composite index, therefore, refers to a crucial extent to the political characteristics of the target. 
To illustrate this phenomenon, the regime type is coded as 'authoritarian' in any type of study when it comes to potential sanctions against Iran. This is considered as an indicator that reduces the likelihood of sanctions success. However, as the Iranian presidential elections and the news headlines showed, Iran's public is more sensitive than we usually expect from an authoritarian regime's citizens against sanctions or any analogous foreign interference. This means that Iranians may have the resources to challenge government policies, which is obviously dependent upon the political and social peculiar conditions. Also, Hufbauer et al. (2007) dataset point out the existence of comparable sanctions cases. During the US sanctions for human rights against Argentina (77-3), there was an authoritarian political system in Argentina. However, Argentina's level of cultural globalization was reasonably high in the US vs. Argentina case, and the outcome of the sanctions was successful. Similarly, sanctions have been successful in the US and the Netherlands / Indonesia (91-4) and Canada / Pakistan (74-3) cases. In the former, an autocracy with a high level of cultural globalization; and a democracy with a low level of cultural globalization has been the target in the latter example, and the both sanctions cases were coded also successful.

Table 1: Sanctions Success with Cultural Globalization and Regime Type Measures

\begin{tabular}{cccccccc}
\hline & \multicolumn{3}{c}{ Cultural Globalization } & \multicolumn{3}{c}{ Regime Type } \\
\cline { 2 - 7 } & Low & Medium & High & Autocracy & Anocracy & Democracy \\
\hline Success & 3 & 20 & 8 & 7 & 12 & 12 \\
\hline Failure & 6 & 20 & 11 & 13 & 12 & 13 \\
\hline
\end{tabular}

Note: Classifications are from lowest to highest cultural globalization levels (1-3); and from autocratic to democratic regime types (1-3). Sources: Raab et al (2007); Hufbauer et al (2007).

In sum, it can be argued that cultural globalization is a practical indicator to predict the relationship between the nature of the political system of the target and sanctions success without specifying a regime type. Accordingly, this argument leads to the following hypothesis:

Hypothesis 1: When the target becomes more globalized, the effectiveness of sanctions increases.

\subsection{Public Perceptions and Sanctions Success}

In some sanctions episodes, the target's leadership can transfer the economic hardship of the population into a resistance cause against the sender's political demands. Galtung (1967) defines this situation as the "rally-around-the-flag-effect" (p. 388). To this end, the masses are often deceived and manipulated by the target's leadership. With the exploitation of the distribution of public goods to the people, the target's leadership generates a "general sense of siege...to maintain political control" (Haas 1997, p.80). For instance, the UN sanctions against Rhodesia and Iraq, produced the aftereffects resembling the symptoms of the "rally-around-the-flag-effect". Therefore, when it comes to imposing sanctions, it can be argued that the 'public effect' may be determined by the target's social development and informational connectedness levels in society. In particular, it is expected that the reasonably more globalized societies are more likely to be exposed to foreign economic and political interference that restricts the range of available strategies for domestic policymakers. Likewise, technological advances and global information flow leads to a more realistic assessment of the pros and cons of the sanctions regime, which may stimulate social awareness among the public that may reduce the "rally-around-the-flag-effect". In other words, since one of the determinants of the effectiveness of sanctions is related to the target costs, perceptions of sanctions and pressure on government policies has an impact on the changes in target state's sanctions behavior. Thus, for example, in authoritarian regimes, it is difficult to persuade the public in the streets to support government policies against sanctions. This argument is valid if the perceptions of sanctions among the public do not contradict the sender's policy goals. How the public perceives sanctions depends, to some extent, on the degree of social change and the policy goals of the sanctions. Human rights as a policy goal, for example, is more likely to be appealing to the target's population than sanctions imposed to realize the sender's any non-appealing objectives.

\section{Policy Goals and Sanctions Success}

Sanctions are an alternative for warfare. Thus, bearing in mind the devastating human and material costs, it can be seen as a relatively peaceful policy option. However, recent experience with the UN sanctions, do not let us consider them as one of the best available policy options. The sanctions against Iraq, for instance, have led to a storm of humanitarian concerns and commenced a dubious debate in which some academics questioned the moral and legal aspects of the use of sanctions (Damrosch 1994; Pierce 1996; Simons 1999). It is true that they are coercive policy tools, aimed at changing the behavior of the target. In other words, in some cases sanctions are against a situation that may jeopardize international peace and security. Sanctions, therefore, substitute the armed conflict as a fundamental policy option. At this point, the role that sanctions play as an alternative to war, may be biased because of the policy goals of the sender. The relative "objectivity" of 
sanctions, therefore, requires the approval of policy goals by the international community. Such a conclusion can be made with regards to the approval of sanctions by the population of the target.

However, the issue of policy goals regarding sanctions often leads to judgmental considerations about the effectiveness of sanctions. As discussed, these concerns may arise not only from the target's side but also from the sender or international actors. For example, the extradition of a terrorist from a country can be justified to the public by policy-makers. In contrast, the activities of a terrorist organization may indirectly serve the national interests of opposing political actors. In this case, terrorists, can be named as freedom fighters in a different context. Under these circumstances, the perceptions in question lead to disagreement over the policy goals of sanctions and the target's behavior towards policy goals. The sanctions would then be flawed that such difficulties can only be mitigated by international pressure on the target state and by the support of the sender's policy goals.

On the contrary, since sanctions are also foreign policy tools, sender may exercise economic coercion with only 'realpolitik' intentions that can lead to similar concerns about the sender's policy goals. Simons, for example, claims that sanctions are often used by the great powers to promote commercial interests to sustain their global hegemony (1999, p.117). Thus, the change in the target's behavior helps the sender to maintain national interests. Similarly, in line with the demonstrative use of sanctions, it can be concluded that the sender does not intend to change the target's initial behavior at all. The sanctions initiated by international and regional organizations may partially meet the necessities for an approval of policy goals. For example, when sanctions are imposed for violations of international peace and security, international support may change the target's behavior, even though sanctions are not successful, as the target finds support from the public and third parties against sanctions.

Policy goals such as the advancement of human rights or democratization have a more problematic nature with regards to international support and target's behavior. As such policy goals are often sought against autocratic regimes; public support against sanctions is thought to be easier to gain. However, not only the political elites manipulate people in the autocratic regimes; but also the public is able to perceive sanctions as against the national independence and well-being, which often leads to pervasive nationalism (Pape, 1996). Furthermore, third-party political actors identify policy goals with ideological pretexts. A policy goal such as human rights and democratization has altered interpretations in different contexts. In sum, if policymakers develop policy goals, arising from the maximization of national interests, the target will naturally find counterpolicies to reduce the likelihood of sanctions success.

Since the focus of the article is the realization of the policy goal or target compliance, what are less disagreeable objectives and how to adjust these to change the target's political behavior and public perceptions of sanctions? The first argument of this research shows that if the level of cultural globalization of the target is high, the sanctions imposed against the target such as human rights will increase the likelihood of sanctions success. In other words, with the help of globalization of the target, the public perceptions of sanctions and the sender's policy goals will be matched, unless the population is satisfied with the target policies. Together with this argument, the public is considered not satisfied with the political system in autocratic regimes and globalization level is considered as a measure that allows the measurement of public approval of global values and standards, as well as a likely measure of public response to internationalized political issues. For example, it can be presumed that a political opposition group exists when sanctions were imposed against the Iranian government. The mobilization of masses against sanctions will be the case as long as the sanctions are against the policies of the existing government and when it is assumed that it is not against the Iranian people. Also, the sanctions against Iran, initiated by an international organization, will not have a positive impact on the outcome of sanctions, as frequently discussed with reference to the negative role of international cooperation on sanctions success.

Unlike the relationship between regime type and people's mobilization against sanctions, the interaction between cultural globalization and policy goals offers a different approach. In the previous explanation, it was argued that target compliance depends on the regime type and the capability of political elites to rally people against sanctions. In the second assumption, it is argued that people's perceptions of sanctions demarcates the conditions of target compliance. If the target population perceives sanctions as a "fair" intervention and not satisfied with the government policies, the outcome of sanctions may be successful. However, cultural globalization as an indicator of public preferences may not fully account for the variation in sanctions success. Evaluating target compliance within the framework of cultural globalization and its impact on the target's population may reflect the overall impact of globalization on the political and social structures of a country. However, public perceptions of sanctions as a variable needs further assessment. Public surveys on how target's population perceive sanctions can explain the impact of public opinion on sanction success more accurately, although the scope of the current analysis does not cover the overall impact of it on sanction success. Similarly, cultural globalization may not accurately measure the level of public awareness of the reflections on internationalization of political issues in a country. However, several variables in the cultural globalization index, such as the political and civil rights of citizens, may serve the necessity to measure the public perceptions of sanctions. In the context of the above discussion, therefore, the following hypothesis can be proposed: 
Hypothesis 2: When the policy objective is human rights, the likelihood of sanctions success increases against a target state with a high level of cultural globalization.

\subsection{Costs to Target, Sanctions Type and Sanctions Success}

Economic costs to the target are considered as one of the priority objectives of sanctions. For that reason, sanctions are known as penalties to change the target's political behavior through economic costs inflicted on the target. Then, sanctions are considered successful when the cost-oriented policy goal is believed to change the target's behavior. However, contrary to the nature of coercive measures, target costs are relatively small. For example, target costs, measured as a percentage of the target's GNP, were 1.4 percent in pre-1985 sanctions episodes, and 3.3 percent in the post-1985 period (Hufbauer et al., 2007, p. 105). Target costs may be small due to the limits of policy goals or to the difficulty of expanding the scope of sanctions and the inclusion of target's some trading partners into the sanctions, and because of the leaks in sanctions that altogether reduce the costs to the target (pp. 105-106). Despite its limits, it can be said that sanctions success and target costs are positively correlated (Hufbauer et al. 2007; Dashti-Gibson et al., 1997; Drury, 1998).

Furthermore, costs to the target depends to "the ability or willingness of the sender to impose costs and the capability of the target to avoid or bear such costs" (Dashti-Gibson et al. 1997, p.609). However, target costs lead to a policy change if it aims the winning coalition of the target. Lektzian and Souva (2007) argue that the significance of economic costs imposed on autocratic leaders will not increase the likelihood of sanctions success. Instead, sanctions are efficacious if the heavy costs are imposed on democratic targets (p.854). Thus, it is argued that autocratic leaders often meet the needs of a small winning coalition and provide mostly special goods to their key constituents. In addition, large economic costs increase the rents in the target state, and therefore, lead to rent-seeking groups to emerge within the target state, benefiting from the consequences of sanctions (p. 852-853).

In this article, it is argued that economic costs imposed on autocratic regimes will be successful if the impact of sanctions is large enough. However, as long as the target has a "chronic" autocratic regime, such as North Korea, costs to the target are less likely to cause a change in target's political behavior. In other words, the argument about target costs continue to have a reasoning similar to the discussion on cultural globalization and regime type. Because of the similarities in regime type classification, having mixed characteristics of both democracy and autocracy, the size of winning coalitions in transitional regimes (anocracy) is a political "grey" area, and therefore, can be broader than expected from these regimes. Therefore, cultural globalization can be used as an indicator of the political behavior of such transitional regimes.

Therefore, it can be argued that wider winning coalitions are not only a feature of democratic states but also some of the autocratic ones. The increase in target costs, which are affected from the process of globalization, increases the likelihood of sanctions success. At this point, the effect of greater costs on target population makes it difficult to assess the main hypothesis in this article. A smaller winning coalition is a reasonable argument for the relationship between the costs imposed on autocratic regimes and the failure of sanctions. In practice, however, the impact of sanctions on the target population and the public's reaction to sanctions are not as indistinguishable as in theory. In sum, it is believed that increased costs will not increase the likelihood of sanctions success in globalized countries, as the increase in costs will lead to negative consequences. This discussion leads to the third hypothesis:

Hypothesis 3: The marginal effect of costs on the target reduces the likelihood of sanctions success when the level of globalization of the target increases

\subsection{Financial Sanctions and Sanctions Success}

The type of sanctions is an important determinant of sanctions success. Comprehensive sanctions include the restriction of export and import, and financial sanctions. Trade sanctions usually have a negative impact on sanctions success because they have more serious consequences on the target and sometimes have a devastating effect on the target population. On the other hand, financial sanctions aim only the interests of some groups within the target. Thus, an empirical evidence was found in favor of financial sanctions (Hufbauer et al. 1990; Drury 1998; Dashti-Gibson et al. 1997). In this article, the effect of financial sanctions will be taken into account and the hypothesis about the type of sanctions is as follows:

Hypothesis 4: Financial sanctions increase the likelihood of sanctions success

\section{DATA AND METHODOLOGY}

\subsection{Data}

Hufbauer et al. (2007) dataset examines 174 sanctions episodes from 1914 to 2000, which is the first large-n dataset and one of the primary references (Nooruddin 2002, p.61). Furthermore, in the empirical evaluation of sanctions success, cultural globalization (the Global Index by Raab et al. 2007) is used as an indicator of sanctions success. Second, the Global Index dataset includes globalization indexes of countries from 1970 to 2002. In the combination of these two datasets, the 
temporal domain of the article is from 1970 to 2000. Therefore, in this article, 72 sanctions cases from Hufbauer et al. (2007) dataset is used to examine indicators of sanctions success. The unit of analysis is the sanction-dyad, composed of a sender and a target.

Although Hufbauer et al. dataset has been widely used and the application of their work has led to a significant improvement in the empirical study of sanctions, the dataset has both its strengths and weaknesses. In general, one of the limitations is the exclusion of pre-World War I sanctions cases. According to Hufbauer et al. (2007) these sanctions cases "are not well-documented and do not seem to address the priorities of today's world" (Hufbauer et al. 2007, 49-50). Compared to the 1990 version of Hufbauer et al. dataset, the new study includes an addition to the temporal domain for a decade. The study increases the number of observations; however, the absence of sanctions concluded at the threat stage also limits the investigation only for implemented sanctions cases.

Defining actors in a sanctions episode vary according to the composition and analysis of each sanction-dyad. In this article, multilateral sanctions episodes were converted into separate observations following the works of Lektzian and Souva (2007) and Nooruddin (2002). Thus, when a sanctions case has multiple senders and targets, they become separate observations. In addition, 11 events have been excluded because of no observed target costs, and observations regarding Iraqi sanctions have also been dropped due to the size of costs to the target. There are also 6 more cases that are omitted due to missing data.

For the Global Index (Raab et al. 2007), the overall data consisted of 31 variables of different globalization indexes, and these indexes provide a standardized weight of each variable. The Global Index examines 116 countries from 1970 to 2002. According to Raab et al.'s (2007) methodology, if there are "more than three missing variables for the entire period", and "up to a third of the variables within the respective sub-dimensions" are missing, these countries are also excluded from the dataset. Therefore, it is possible to use sanctions cases only after 1970 with the data from the Global Index. In addition, if sanctions include one of the countries that is not included in the Global Index dataset, these observations are excluded from the existing analysis. With this selection method, the number of observations are 72 sanctions cases.

\subsection{Dependent Variable}

The reliability of a variable is about the consistency and repeatability of the measurement. DeVaus (2001) defines reliability according to the repetition capacity of it in different situations (p.30). However, at the expense of validity, quantitative analysis leads to more precise but less accurate measures (King et al. 1994, p.151). In this sense, measuring sanctions success as dependent variable is one of the puzzling tasks. For this purpose, most scholars rely on Hufbauer et al. (2007) data, which has two different dependent variables, i.e. "result" and "contribution". Each variable is based on a scale, ranging from 1 to 4 . The "result" is a measure based on the four policy objectives of the sender: "failed outcome", "unclear but possibly positive outcome", "positive outcome" and "successful outcome". The "contribution", on the other hand, is a judgmental measure of the policy goal that ranges from "negative contribution" and "little or no contribution" to "substantial contribution", "decisive contribution". As a result, "success" is the multiplication of these two measures, ranging from 1 to 16 and distinguishes a score of 9 or higher as a successful outcome (pp.49-50).

Hufbauer et al. (2007) dataset "depends on the qualitative results achieved by the academicians of individual departments (p.49). Therefore, with regard to the use of the composite "success" measure, some scholars argue that "there is no theoretical, empirical or statistical reason for the policy outcome to be multiplied by another variable designed to assess the contribution of sanctions to the observed result" (Gibson et al., 1997). Therefore, the "success" measure as a composite variable, success as a dependent variable, and explanatory variables that are independent of the result of the contribution threaten the validity of the dependent variable (Hufbauer et al. 2007, p.183). Simply put, the addition of the contribution violates "the assumption that the dependent variable is exogenous" (Drury 1998, p.500). Consequently, using the same dataset, many scholars only use the "result" as the dependent variable. The "result" is also used in this article as a dependent variable to address the avoidance of systematic measurement errors that prevent descriptive inferences (see King et al. 1994, p.155-156).

Therefore, RESULT, as coded by Hufbauer et al. (2007), is scaled from one to four: " $1=$ failed outcome", " $2=$ unclear but possibly positive outcome", " $3=$ positive outcome", " $4=$ successful outcome". In this article, the logistic regression used in the empirical analysis requires a dichotomous dependent variable, which reduces this scale into two values. Observations with positive results ( 3 and 4 ) are coded as successful ( 1 ) and others ( 1 and 2 ) are coded as failure (0). In order to clarify this scaling, the "failure" can be cited as the Soviet's attempt to destabilize the Tito regime in Yugoslavia (case-48). The US and Saudi efforts to reduce Jordan's support for Iraq during the First Gulf War indicate "an uncertain but possibly positive outcome". In addition, the United States' attempts to promote democracy in Latin America in the 1970s are regarded as a "positive" outcome. The overthrow of the Idi Amin government in Uganda can be exemplified as a "successful" outcome (case 72-1) (Hufbauer et al. 2007, p. 49-50). Lektzian and Souva (2007), Dashti-Gibson et al. (1997) and Nooruddin (2002) are some of the examples of following similar coding rules for the dependent variable. 


\subsection{Independent Variables}

\subsubsection{Cultural Globalization}

The main argument of this article is to measure sanctions success through the cultural globalization index, which substitutes the use of regime type as an independent variable. Moreover, cultural globalization indirectly affects policy goals and the type of sanctions. The secondary role of cultural globalization is discussed in the sections on human rights and financial sanctions. Thus, the level of cultural globalization of the target is a measure from the Raab et al. (2007) dataset. Cultural globalization is an index of 8 different variables. These are classified into sub-groups in which the "logic of expansion" includes variables such as the urban population and the percentage of high technology exports in manufactured exports. Second, the variables in the "values and standards" group include the Freedom House Index (civil liberties and political rights), primary school enrollment, total school enrollment, total education expenditure, and the number of McDonald's restaurants.

Cultural globalization reflects partly the political system of the target state, but more importantly, it gives an idea about the people's possible reflections about the sanctions in the target. The second component of cultural globalization represents an interactive measure of public preferences, as opposed to the implicit estimation of it in the regime-type typology. In other words, some autocratic regimes are assumed to have a larger winning coalition and higher audience costs than prima facie assumptions. Data for CULGLOB is from Raab et al. (2007), as a continuous variable ranging from 1 to 10 . Instead of using a dichotomous variable in the article, the original coding style of the index serves the basic logic of globalization that points to a process of change in terms of socio-economic and political development.

Table 2: Distribution of Cultural Globalization Scores

\begin{tabular}{cccccc}
\hline \multicolumn{7}{c}{ Cum. } & & Cum. \\
\hline $\mathbf{1 - 1 . 5}$ & 0 & 0 & $\mathbf{5 - 5 . 5}$ & 14 & 66 \\
\hline $\mathbf{1 . 5}-\mathbf{2}$ & 1 & 1 & $\mathbf{5 . 5 - 6}$ & 10 & 76 \\
\hline $\mathbf{2}-\mathbf{2 . 5}$ & 3 & 4 & $\mathbf{6 - 6 . 5}$ & 6 & 82 \\
\hline $\mathbf{2 . 5}-\mathbf{3}$ & 6 & 10 & $\mathbf{6 . 5 - 7}$ & 10 & 92 \\
\hline $\mathbf{3 - 3 . 5}$ & 4 & 14 & $\mathbf{7 - 7 . 5}$ & 3 & 95 \\
\hline $\mathbf{3 . 5}-\mathbf{4}$ & 7 & 21 & $\mathbf{7 . 5 - 8}$ & $\mathbf{2}$ & 97 \\
\hline $\mathbf{4 - 4 . 5}$ & 14 & 35 & & & \\
\hline $\mathbf{4 . 5 - 5}$ & 17 & 52 & & & \\
\hline
\end{tabular}

Source: Global Index, Raab et al. (2007)

\subsubsection{Costs to Target}

In sanctions research, target costs are used as an important indicator of sanctions success (Hufbauer et al. 1990; Lam 1990, Dashti-Gibson et al. 1997, Hart 2000). These are the costs measured as a percentage of the GNP of the target. The expected cost for the target includes restrictions on exports and imports and the flow of financial assets (Hufbauer et al., P.44-45). The TCOST is used as an indicator of target costs. Data for TCOST comes from the Hufbauer et al. (2007) dataset. Moreover, to measure target costs as a separate explanatory variable, as the institutional theory suggests, the costs that are inflicted on the winning coalition of the target have an impact on sanctions success (Lektzian and Souva 2007). Thus, the same logic is used to analyze the costs of the target through cultural globalization levels. CULCOST is a product of the CULGLOB and TCOST variables.

\subsubsection{Human Rights}

Another key to sanctions success is the type of policy goals. In relation to a hypothesis on policy goals, it is assumed that the target's preferences and policy goals have a relationship with sanctions success. If policy objectives are not against the public preferences; and if domestic policies and the public opinion are in conflict, these two conditions may have an impact on sanctions success. The HRGOAL variable is included to measure such an impact on sanctions success. The HRGOAL variable is coded as, "1", otherwise "0". Both Hufbauer et al. and Raab et al. (2007) datasets were used to establish this dummy variable.

\subsubsection{Control Variables}

Sanctions success is often estimated through a number of other determinants such as the economic weakness of target state, assistance to the target and international cooperation. These variables are included in the empirical models of the article for two reasons: First, it is assumed that these three separate variables have an impact on the target compliance for theoretical purposes. Second, the use of these determinants helps to understand the general value and location of the empirical model, as such variables are frequently used in sanctions research. 
Thus, political instability and the economic weakness of the target are one of the indicators of sanctions success. In cases where the political and economic indicators of the target are more unstable, the sanctions are more successful (Hufbauer et al. 1990; Lam 1990). Targets, with unhealthy economic and political conditions, are more likely to meet the demands of the sender (Drury 1998, p.500). Hufbauer et al. (2007) included economic weakness and political instability on a scale of 1 to 3 in their empirical analysis. Accordingly, this scale takes the following values: "distressed country (coded as 1)"; "country with significant problems (coded as 2)"; "strong and stable country (coded as 3)". On this scale, the "distressed country" is characterized by acute economic problems such as high inflation and unemployment, and political turmoil. "Countries with significant problems" are associated with serious economic problems such as currency crisis and internal opposition. Finally, "normal economic indicators" can be attributed to a strong and stable country without all of these problems (p.62-63). For the TSTABILITY variable, Hufbauer et al. (2007) data and coding style is used in this article.

In order to reduce costs, the target often avoids the effects of sanctions by means of leaks in the sanctions regime, as long as they are able to maintain external partnerships and foreign assistance. Since the objective of this article is to examine the target compliance, third-party assistance to the target becomes part of the empirical models. The dichotomous TASSIST variable is used to measure the assistance to the target. Data for TASSIST comes from the Hufbauer et al. (2007) dataset, if there is assistance to the target, the dummy variable takes the value of "1", otherwise "0".

International cooperation has a positive relationship with sanctions success because more cooperation between sender states means that sanctions are going to be more effective with regards to restrictions on the target. With international cooperation, sanctions may set up trade conditions that generate rents for autocrats, as well as encourage others to leak and trade in the sanctions coalition (Kaempfer and Lowenberg 1999). Thus, international cooperation has no positive effect on sanctions success in practice. This article uses the INTCOOP variable to see if any such implications exist in the empirical model. International cooperation data comes from Hufbauer et al. (2007), ranges from 1 (no cooperation) to 4 (significant cooperation).

In the relationship between the type of sanctions and sanctions success, financial sanctions contribute more than other types of sanctions to the outcome. For example, import and export sanctions have a devastating effect on the target, as they are more likely to impact the general population. Instead, financial sanctions are aimed at political elites, especially in autocratic regimes. FINS variable is coded as " 1 " if they are financial, and " 0 " otherwise. Data for FINS comes from Hufbauer et al. (2007) dataset.

Finally, the US is included in the empirical model as a control variable. Since the United States is one of the leading sender states, the impact of the US on the success of sanctions thus should be taken into account.

Table 3: Descriptive Statistics

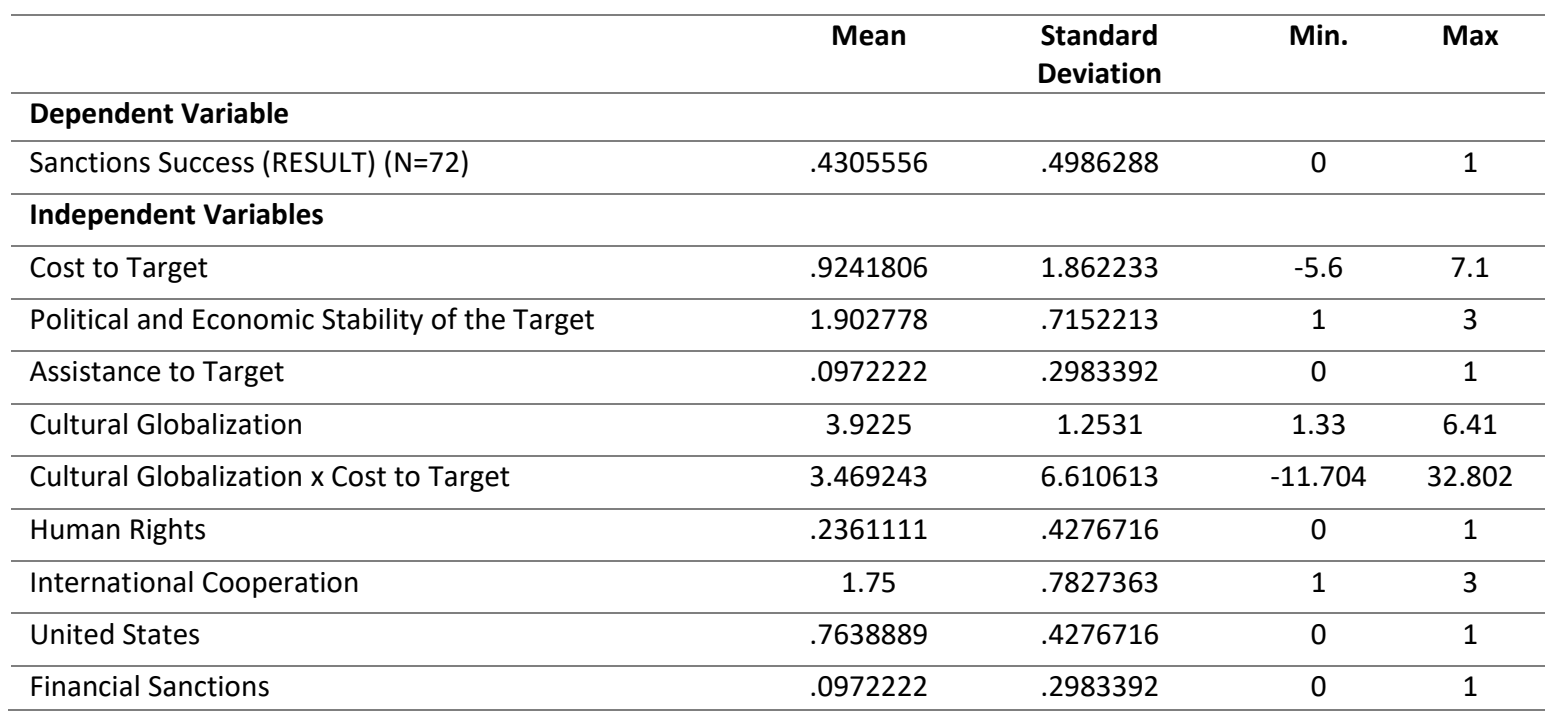

\subsection{Empirical Model}

The analysis of sanctions onset and success are based on case studies. Yet, empirical studies, especially after the Hufbauer et al. (1990) dataset, have gained importance. The dataset, which is the main source of empirical studies in this area of study, has been criticized for the model specification and judgmental success score. For example, Bonetti (1997) claims that the model in Hufbauer et al. study is weak in explaining the variation in the success score. The weaknesses in the evaluation 
of the success in Hufbauer et al. are due to the use of OLS estimate. Thus, for example, among others, van Bergeijk (1994) and Drury (1998) used logistic regression models, and Lam (1990) used the probit model. Furthermore, van Bergeijk (1994) indicates that the arbitrary choice of the dependent variable in the regression model of Hufbauer et al. Bergeijk criticizes the inclusion of the contribution variable as part of the dependent variable since it is considered as one of the determining factors of sanctions success (p. 73). Hufbauer et al. (2007) use the binary logistic regression model in the last edition of the dataset. Though, they found that ordered logistic regression violates parallel regression assumptions (p.187). In this article, two probit models are used to analyze the hypotheses. In the model, dichotomous dependent variable "result" is also used at Hufbauer et al. (2007) study.

The probit model for the empirical analysis of sanctions success is as follows:

$$
\begin{aligned}
\operatorname{prob}(\text { RESULT })= & \beta_{1}(\text { TCOST })+\beta_{2}(\text { TSATIBILITY })+\beta_{3}(\text { TASSIST })+\beta_{4}(\text { CULGLOB })+\beta_{5}(\text { CULCOST })+e \\
\operatorname{prob}(\text { RESULT })= & \beta_{1}(\text { TCOST })+\beta_{2}(\text { TSATIBILITY })+\beta_{3}(\text { TASSIST })+\beta_{4}(\text { CULGLOB })+\beta_{5}(\text { CULCOST })+\beta_{6}(\text { HRGOAL })+ \\
& \beta_{7}(\text { INTCOOP })+\beta_{8}(\text { US })+\beta_{9}(\text { FINS })+e
\end{aligned}
$$

\section{FINDINGS AND DISCUSSIONS}

Table 5.1 presents the empirical findings of the article. In the first model, in addition to the TCOST, TSTABILITY and TASSIST variables, the main interest is based on the impact of cultural globalization on sanctions success and the conditional impact on target costs. The first probit model represents the arguments in the discussion of hypothesis 1 . The second model has supplementary variables such as HRGOAL, INTCOOP, FINS, and US. For the first model, the aim is to understand the impact of cultural globalization and the impact of variables directly related to the target characteristics. In the second model, the attention is given to the assessment of the consistency of model 1 variables in a wider context.

In both, the overall significance of the empirical models is shown by considering the Wald Chi-square statistics. Pseudo Rsquare statistics are explanatory for variation in binary logistic regression models with 29 percent for the first model and 35 for the second model. Four of the five independent variables are statistically significant in the first model. 3 of these 4 variables were found to be significant at 99 percent level. In the second model, 6 variables out of 9 were found to be significant. Significant variables were also found to be significant in the second model. Finally, the constant terms in both models are also statistically significant. As expected, the hypothesis of the relationship between the target's level of cultural globalization and sanctions success is significant at 99 percent in both empirical models. Therefore, as target becomes more culturally globalized, the likelihood of sanctions success increases.

Table 4: Empirical Results for the Probability of Sanctions Success

\begin{tabular}{lll}
\hline \multicolumn{2}{l}{ Model $\mathbf{1}$} & Model 2 \\
\hline Dependent Variable & & \\
\hline Sanctions Success (RESULT) (N=72) & & \\
\hline Independent Variables & $2.37^{* *}$ & $3.00^{* * *}$ \\
\hline Cost to Target (TCOST) & $(0.949)$ & $(1.026)$ \\
\hline Political and Economic Stability of the Target (TSTABILITY) & $-0.88^{* * *}$ & $-0.83^{* * *}$ \\
& $(0.254)$ & $(0.310)$ \\
\hline Assistance to Target (TASSIST) & -0.04 & -0.26 \\
& $(0.649)$ & $(0.670)$ \\
\hline Cultural Globalization (CULGLOB) & $0.82^{* * *}$ & $1.09^{* * *}$ \\
& $(0.202)$ & $(0.261)$ \\
\hline Cultural Globalization x Cost to Target (CULCOST) & $-0.53^{* * *}$ & $-0.66^{* *}$ \\
& $(0.205)$ & $(0.218)$ \\
\hline Human Rights (HRGOAL) & & 0.20 \\
& & $(0.532)$ \\
\hline International Cooperation (INTCOOP) & & -0.42 \\
& & $(0.245)$ \\
\hline United States (US) & & $1.29^{* *}$ \\
& & $(0.534)$ \\
\hline Financial Sanctions (FINS) & & $1.10^{*}$ \\
\hline constant & & $(0.671)$ \\
\hline Observations & & $-3.85^{* *}$ \\
\hline
\end{tabular}




\begin{tabular}{lll}
\hline Pseudo R-squared & 0.29 & 0.35 \\
\hline Wald Chi-squared & 23.01 & 24.95 \\
\hline Notes: Statistical significance is as follows: $\mathrm{p}<0.10\left({ }^{*}\right), \mathrm{p}<0.05(* *)$, and $\mathrm{p}<0.01(* * *)$ & &
\end{tabular}

Notes: Statistical significance is as follows: $p<0.10\left(^{*}\right), p<0.05(* *)$, and $p<0.01\left({ }^{* * *}\right)$.

Robust standard errors clustered by target and are given in parentheses.

Empirical evidence has been found in both empirical models as indicated in the relationship between sanctions success and cultural globalization, since cultural globalization is used as an indicator that replaced the regime type and also due to the presumed relationship between winning coalitions and cultural globalization. In fact, there are also examples in the dataset that help combine cultural globalization as a measure of target's features regardless of the regime type. For example, in the United Kingdom vs. Argentina (1983) and the United States vs. Indonesia (1991) cases, sanctions were successful when the sender was democratic and the target was non-democratic. Similarly, in the case of Australia vs. France (1983), both sides are a democracy and the result of sanctions is successful. Finally, in China vs. France, the sanctions are successful while the sender is autocratic and the target is democratic. In other words, such examples support the hypothesis presented in this article.

'As highlighted in some scholars' pieces (Hufbauer et al. 1990; Lam 1990; Jing et al. 2003; Dashti-Gibson et al. 1997), TCOST is statistically significant in the explanation of the RESULT in both models that an increase in target's economic costs increases the likelihood of sanctions success. The interaction term, CULCOST, is negatively significant. However, interpreting the interaction term from the results table can be misleading. The slope line in Figure 1 shows how the marginal effect of cost to target changes with the cultural globalization level. Cost to target has a positive impact on sanctions success when the cultural globalization level is quite low. This influence decreases as the level of cultural globalization increases. When the level of cultural globalization reaches 2.5 , this effect is no longer significantly important. In contrast, when the level of cultural globalization is relatively high, costs to target have a negative impact on sanctions success. Also, when the cultural globalization score is above 4 , the costs have a negative effect on sanctions success. However, in practice, there are only 4 countries under 2.5 level and 76 countries are over 4 level. Therefore, when the level of cultural globalization of the target is high, we can conclude that the costs to the target negatively influence the outcome of sanctions.

Figure 1: Marginal Effect of Target Costs Conditional on Cultural Globalization Level

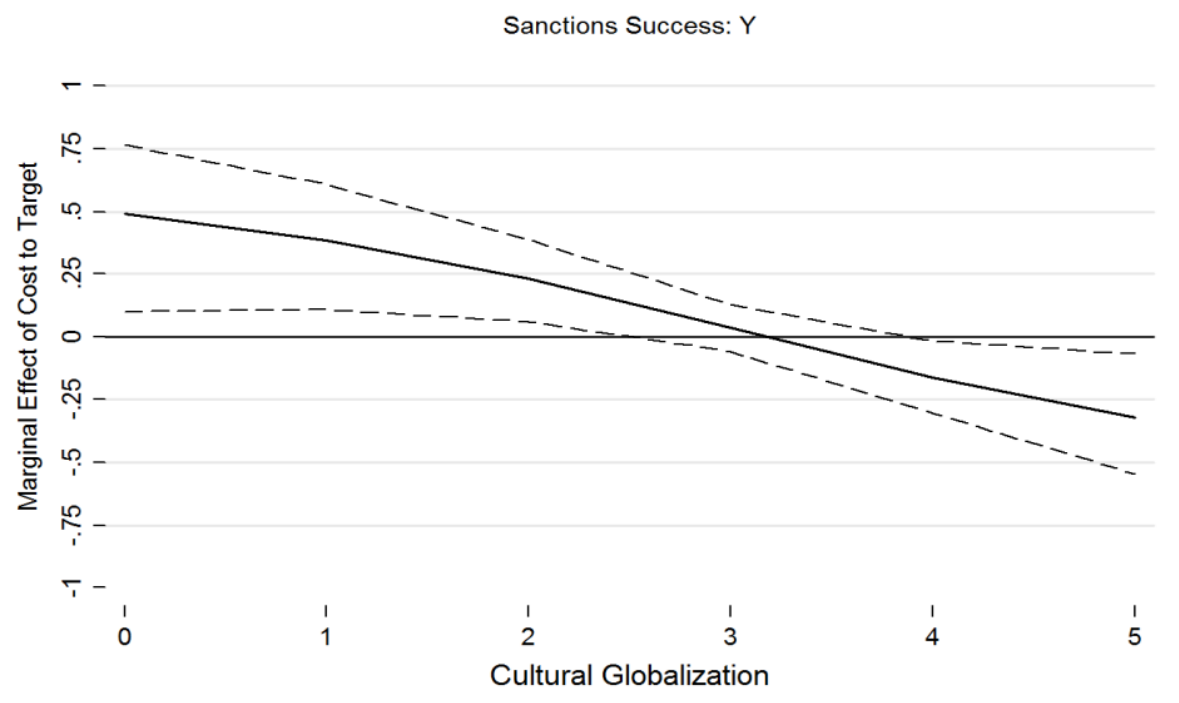

Scholars have found empirical evidence to support the positive relationship between modest policy goals and sanctions success (Dashti-Gibson et al., 1997). Yet, as a separate measure, policy goals are not statistically significant. In this article, the impact of cultural globalization on public opinion has been evaluated. How the target's public perceives sanctions is a key to sanctions success. Therefore, since cultural globalization leads to social change, which means adapting to the global values and standards in the target's society, the kind of policy goals that are supported by the target population has become the main point of the hypotheses. In this context, it has been proposed that as the policy goal of sanctions is human rights, the likelihood of sanctions success may increase if the target is a more globalized country. Thus, a significant relationship was found between $H R G O A L$ and sanctions success. 
Financial sanctions are more effective tools than trade sanctions (Hufbauer et al., 1990; Drury 1998; Dashti-Gibson et al. 1997). An explanation for such an inference is that they reduce the target costs imposed on the target population, as financial sanctions mostly aim a country's political elites. On the contrary, trade sanctions have the opposite effect because costs are more likely to affect the target's population. Although FINS does not have any statistical significance, it is positively associated with sanctions success, thus, supports the existing conventional view in sanctions research.

Empirical findings of the link between political and economic stability of the target and sanctions success are similar to the studies of Hufbauer et al. (1990), Lam (1990) and Jing et al. (2003). In addition, the international cooperation INTCOOP, as found by the findings of Hufbauer et al. (1990) and Drury (1998), have a negative impact on sanctions success. However, in the second model, it was not statistically significant. Finally, assistance to target is not significant. However, it confirms the negative impact on the likelihood of sanctions success (Hufbauer et al., 1990; Drury, 1998).

\section{CONCLUSION}

Scholars of sanctios has long displayed an interest in the political and economic determining factors of sanctions efficacy, however, ignored cultural and historical determinants of target state's political behavior (Kaempfer and Lowenberg 2007, pp. 904-905). In this article, the impact of cultural globalization on state behavior and people's preferences, is examined. Economic globalization is highly represented in the literature, but cultural globalization has not been studied as an indicator of target's compliance. . In particular, cultural globalization leads to political change that paves the way for a transitional political system for these countries. Thus, in the case of culturally globalized targets, referring to the selectorate theory, it is claimed that the winning coalition is wider and the scope of this coalition can be determined without a regime type. In addition, cultural globalization leads to social change that transforms public preferences. Similarly, it can be argued that the audience costs are higher in culturally globalized states as these costs require a publicly accepted and known foreign policy behavior. As democratic leaders act with a motivation for re-election and the preferences of the population are taken into account in the decision-making, similar assumptions can be made for the leaders of culturally globalized states. At that point, culturally globalized states tend to comply with sender's demands on the grounds that the target resolve is not credible and the leaders do not change their declared policy behavior. In addition, hypotheses on the impact of policy goal on public perceptions of sanctions were also examined. Policy goals, such as human rights, are considered to be relatively acceptable sanctions objectives as they can be perceived as acceptable and in line with the target population's motivations.

Therefore, the hypotheses in this article provide empirical evidence of the relationship between cultural globalization and sanctions success, and in part, reflect the target's behavior and population's preferences. However, explaining the sanctions success based on a set of explanatory variables adopted by the traditional view is insufficient to explain the sanctions space. Although cultural globalization partly contributes to predict the variation in sanctions success, the estimation of sanctions success with explanatory variables continues to be beyond the acquisition of modern econometric methods and political and economic theories (Hufbauer et al. 2007, p.192). To these ends, measures such as public perceptions of sanctions should be included in the priorities of further research agenda.

\section{REFERENCES}

Allen, S. H. (2005). The determinants of economic sanctions success and failure. International Interactions, 31, 117-138.

Baldwin, D. (1985). Economic statecraft. Princeton: Princeton University Press.

Bolks, S. M., Al-Sowayel, D. (2000). How long do economic sanctions last? Examining the sanctioning process through duration. Political Research Quarterly, 53, 241-265.

Bueno de Mesquita, B., Smith, A., Siverson R. M., Morrow, J. D. (1999). An institutional explanation for the democratic peace. American Political Science Review, 93, 791-808.

Bueno de Mesquita, B., Smith, A., Siverson R. M., Morrow, J. D. (2003). The Logic of Political Survival. Cambridge, MA: MIT Press.

Dashti-Gibson, J., Davis, P., Radcliff, B. (1997). On the determinants of the success of economic sanctions: an empirical analysis. American Journal of Political Science, 41 (2), 608-618.

DeVaus, D. A. (2001). Research design in social research. California: Sage Publications.

Drezner, D. W. (1998). Conflict expectations and the paradox of economic coercion. International Studies Quarterly, 42, 709-731.

Drezner, D. W. (1999). The sanctions paradox: economic statecraft and international relations. New York: Cambridge University Press.

Drezner, D. W. (2001). Outside the box: explaining sanctions in pursuit of foreign economic goals. International Interactions, 26 (4), $379-$ 410. 
Drury, A. C. (2000). How and whom the US president sanctions: A time-series cross-section analysis of us sanction decisions and characteristics. In Chan, S., Cooper, D. A., Sanctions as economic statecraft: theory and practice, New York: St. Martin's Press.

Eland, I. (1995). Economic sanctions as tools of foreign policy. In Cortright, D., Lopez, G. A., Economic sanctions: panacea or peacebuilding in a post-cold war world?. Boulder: Westview Press.

Fearon, J. D. (1994). Domestic political audiences and the escalation of international disputes. American Political Science Review, 88, 577592.

Galtung, J. (1967). On the effects of international economic sanctions: with examples from the case of Rhodesia. World Politics, 19 (3), 378416.

Galtung, J. (1966). On the effects of international economic sanctions. World Politics, 19, 411.

Hufbauer, G., Schott, J., Elliott, K., Oegg, B. (2007). Economic sanctions reconsidered (3rd edition). Washington: Peterson Institute for International Economics.

Hufbauer, G., Schott, J., Elliott, K. (1990). Economic sanctions reconsidered (2nd edition). Washington: Peterson Institute for International Economics.

Hufbauer, G., Oegg, B. (2006). Economic sanctions for foreign policy purposes: A survey of the twentieth century. In Kerr, W.A., \& Gaisford, J. D., Handbook on international trade policy, Cornwall: Edward Elgar Publishing.

Kaempfer, W. H., Lowenberg, A. D. (2000). A public choice analysis of the political economy of international sanctions. In Chan S., \& Drury, A. C., Sanctions as economic statecraft: theory and practice, New York: St. Martin's Press.

Kaempfer, W. H., Lowenberg, A. D. (2007). Political economy of economic sanctions. In Sandler T., \& Hartley, K., Handbook of defense economics.

Kaempfer, W. H., Lowenberg, A. D. (1992). International economic sanctions: A public choice perspective. Boulder: Westview Press.

King, G., Keohane, R. O., Verba, S. (2006). Designing social inquiry: Scientific inference in qualitative research. New Jersey: Princeton University Press.

Lektzian, D., Souva, M. (2003). The economic peace between democracies: Economic sanctions and domestic institutions. Journal of Peace Research, 40 (6), 641-660.

Lektzian, D., Souva, M. (2007). An institutional theory of sanctions onset and success. Journal of Conflict Resolution, 51 (6), $848-871$.

Lopez, G. A., Cortright, D. (1995). Economic sanctions in contemporary global relations. In Lopez, G. A., Cortright, D., Economic sanctions: panacea or peace-building in a post-cold war world?. Boulder: Westview.

McGillivray, F., Smith, A. (2000). Trust and cooperation through agent-specific punishments. International Organization, 54, 809-824.

Nooruddin, I. (2001). Modeling selection bias in studies of sanctions efficacy. International Interactions, 28, 59-75.

Nossal, K. R. (1999). Liberal democratic regimes, international sanctions, and global governance. In Vayrynen, R., Globalization and global governance, Lanham: Rowman and Littlefield.

Pape, R. (1997). Why economic sanctions do not work?. International Security, 22 (2), 90-136.

Raab, M., Ruland, M., Schönberger, B., Blossfeld, H-P., Hofäcker, D. (2007). Globallndex - a multidimensional approach to globalization measurement. http://www.transeurope-project.org

Simons, G. (1999). Imposing economic sanctions: Legal remedy or genocidal tool?. London: Pluto Press.

Tomz, M. (2007). Domestic audience costs in international relations: an experimental approach. International Organization, 61, pp. 821-40. 